\title{
ROLE OF AIR CARGO AND ROAD FEEDER SERVICES FOR REGIONAL AIRPORTS - CASE STUDIES FROM THE BALTIC SEA REGION
}

\author{
Anatoli Beifert ${ }^{1,2}$ \\ ${ }^{1}$ Tallinn University of Technology \\ Ehitajate tee 5, 19086 Tallinn, Estonia \\ ${ }^{2}$ Wismar University of Applied Sciences \\ Philipp-Müller Str. 14, 23966 Wismar, Germany \\ Ph.: +493841 753634; anatoli.beifert@hs-wismar.de
}

\begin{abstract}
Although airports play an important role the global and European economies, according to the new guidelines of the EU Commission on the new state aid rules for a competitive aviation industry (EC, 2014), it will be more difficult for unprofitable airports, to get financial public subsidies in the future. The Commission noted that the majority of regional airports experience severe problems to cover their operative costs, resulting from among other things from overlapping of airports' catchment areas. The main objective of the above mentioned measures is not to close the regional airports, but to motivate them to operate on cost efficient, profitable and more flexible basis, stating however that and that the most inefficient airports will be still closed. In order face upcoming challenges, the regional airports shall reconsider their future development plans. Traditionally, the airports including small and regional airports focus on the passenger traffic and thus, the possible benefits and opportunities of the air cargo market are totally underestimated or even completely ignored. Most regional airports in the Baltic Sea region act totally isolated and do not have a clear picture of the current situation on the international air cargo market today, its future perspectives and sustainable development plans remain basically hidden. There are some examples when trying to meet the market demand, the regional airports have made huge, but unfortunately unjustified investments, e.g. improving airport infrastructure, runways, etc. However, the airports' infrastructural investments alone cannot fulfil the expected "remedy" role for the airports' sustainability. This paper aims at investigating the positioning and the role of the regional airports in the current hub-and-spoke network, focusing on the relevance and potential of the air cargo sector for the regional airports development. The optional freight value proposition for the development of the regional airports and their possible participation in the air cargo market as a supplement instrument to generate additional revenue also by means of so-called "air trucking" services will be presented and discussed.
\end{abstract}

Keywords: regional airports, air cargo, air trucking, road feeder services

\section{Introduction}

Aviation plays an essential role in the European socio-economic development. With a network of more than 440 airports, and more than 60 air navigation service providers, the European aviation industry carries about $40 \%$ of Europe's exports and imports value, and transports over 822 million passengers annually to and from Europe (Crabtree et al., 2015). European airports employ directly or indirectly over a million people. As it stated in the EU Competition Policy Brief, European airports improve access to remote regions facilitating market access for regional businesses. For some remote regions the air accessibility is only possible is of a special importance (Horst, 2006). On the other hand the European Court of Auditors registered that ca. $48 \%$ of European airports as loss making in 2014. In spite of the current losses the regional or national public authorities keep on supporting the airports in order to provide accessibility and public socio-economic obligations (EU Commission, 2014). As it further mentioned in the Competition Policy Brief 2014 on the new state aid rules for a competitive aviation industry, the subsidies from the EU, national or regional public funds will be considerably cut unprofitable airports. Therefore, it might be stated that EU Commission has sent a clear message that expanding financial aid to airports could not be a sustainable solution in the future. Increased competitive environment between the airports in Europe (Fewings, 1999), liberalisation and deregulation process in aviation industry, the end of protectionism era is putting much pressure on airports to increase their performance levels (Reis \& Macário, 2009). The reduction of the public support for European regional airports has also contributed to the increase of uncertainty for the airports and airports operators and shall motivate them for more flexible strategic planning, considering possible alternative development models (Crabtree et al., 2015). Traditional approach in strategic, operational and tactical planning nowadays cannot enhance airports' competitiveness in the 
constantly changing market conditions (Neufville, 2008). Considering current financial difficulties of the European airports (especially of regional airports) and the relatively high costs in case of airport's infrastructure upgrade, the airports shall increase their ability to have the airports' hard infrastructure as convertible and mutable as possible in order to be able adapt to the current infrastructure without permanent change to current and future needs with minimal financial investments (Schuchi et al., 2012; Margalhaes et al., 2013). Margalhaes stated that flexible airports compared to ,non-flexible“ possess certain advantages to keep their performance results over the operational time period in more sustainable way. This approach shall be of a special importance to the airports and airports' operators, since even the minimal changes in the airport's infrastructure might require considerable financial, personal and time resources. Thus, the variety of options and alternatives of business and service models in the nearest operational environment shall offer airports considerable competitive advantage in comparison to airlines (Beifert, 2015). The study of the air cargo market of Boeing: "World Air Cargo Forecast 2014-2015" reveals that in average air cargo business represents $15 \%$ of companies' total turnover, whereas the passenger business may be characterized by relatively low margins (up to 7\%). Boeing stated that international airfreight would drive global air cargo growth up to 2033 with an average annual overall air cargo traffic growth up to 4,7\% over the next 20 years (Boeing, 2015). Thus, air cargo business can be an important source of revenues and be a driving force for a company's profitability. Following Kasarda and Green (2005) analysis, it might be further stated that airfreight regardless of location improves regional and national accessibility through efficient connectivity to distant markets and global supply chains in a speedy and reliable manner. Therefore, the regions with efficient air cargo connectivity will have competitive trade and production advantage (Kasarda \& Green, 2005). On the other hand, it is to be noted that some authors noted that the real market power of an airport depends heavily on the market segment and the availability of the airports in the proximity. As airports' competition for air cargo is very challenging in Europe, where the airports might be only several hours away from each other by road, air cargo transport may be regarded as a "foot-loose" and a tough business (Starkie, 2002).

In the framework of the EU funded project "Baltic.AirCargo.Net" (BACN) a number of regional airports in the Baltic Sea Region have been analysed aiming at evaluating potential of the air cargo for airport development. The findings of the BACN project showed that the volume currently transported by air in the regional airports is very insignificant and almost entirely based on the occasional charter flights. However, the growth of the air cargo business for some regional acting as feeder-spokes in an airport network system is likely to be based not on pure or dedicated air freighters, but to a larger extend on truckor road based air services - also called as "Road Feeder Services".

This paper is organised as follows: the theoretical framework showcases theoretical approaches to regional airports, airports' hub-and-spoke network, corresponding network positioning of regional airports and air cargo role for the regional airports' development. The following section presents the methodology and results of the cases investigated, formulating implications of Road Feeder Services concept as an optional freight value proposition for the development of the regional airports and their possible participation in the air cargo market as a supplement instrument to generate additional revenue, thus making the airports more profitable and attractive.

\section{Theoretical background}

There are ca. 500 commercial airports in Europe that could be grouped into two categories: 1) Hub airports, providing a full range of services, e.g. business or leisure passenger traffic, domestic, or intercontinental flights as well as airfreight services. The hub-airports consolidate the air traffic from smaller and regional airports or provide the final-leg air connection to them; 2) Regional airports that feed hub-airports with passenger and air cargo and in some cases provide direct flights to other regional airports, herewith fulfilling the connection function to the centres of socio-economic activity. (Horst, 2006). Huband-spoke network pattern has been introduced and developed in the aviation world in the United States since the early 1980s, triggered by the enforcement of the Airline Deregulation Act in the USA in 1978 (White, 1979; Dennis, 1994; US Congress, 1978), which promoted considerable deployment of the huband-spoke network structures for the airports and airlines operations worldwide, and contributed also to the overall costs' reduction both for passenger and air cargo traffic (White, 1979; Wei, 2006). Since 1979 new airlines were allowed to enter the aviation industry and choose the routes they would like serve and the fares they would charge on their own (White, 1979). This liberalisation simplified also the bankruptcy 
procedure for the airlines, which considerably increased the competitive environment and rush development of the aviation industry worldwide (Bauer, 1987). In the hub-and-spoke network model the flight routes consist of the central point (named as "hub"), which serves several ends ("spoke"). Hub functions as a consolidation point of passengers and airfreight that move from the various spokes and provide connecting flight to other destination points that might be other national or international hubs or spokes (Dennis, 1994). The network airlines may operate inter-hub flights several times a day with a high range and capacity aircrafts, which accept input of passenger and cargo from locations close to the hub. The airlines are also arranged for a hub-and-spoke, using smaller aircraft, to provide a higher frequency flights, feeding the hub with a number of spokes' connections (Sugiyatoa et al., 2015). Hub selection is based on the location and relatively high market demand for a pair of "origin-destination" in favour of flight-operations (Rietveld et al., 2001). Rietveld et al. state also that some airport-hubs build partnerships with regional airline operator(s) or establish a subsidiary-network to remote area. The advantages of hub-and-spoke networks have been analysed by various authors that discussed the effects of hub on airline / airports' costs and profitability. An airport-hub might allow the airlines to serve routes more frequently with larger aircraft at higher load factors, thus reducing costs (Bailey, 1985). Morrison and Winston (1986) investigated the effects of hub, stating that passengers basically benefit from the hub-and-spoke pattern through availability of more frequent flights with lower fares, shorter travel times and improved accessibility to remote regions.

In spite of the fact that the airline deregulation progressed relatively slowly in Europe, it acted however also as the main driving force for the airports' and airlines competition, decreasing fares and thus stimulating demand for the aviation services considerably (Reis \& Macário, 2009; Barett, 2000). Generally, it may be stated that the growth of hub-and-spoke network model enabled large and medium size airports to become the dominant airport hubs in their respective regions, herewith increasing competitiveness pressure on regional airports (Bootsma, 1997; Reynolds-Feighan, et al., 2006; Matsumoto et al., 2008; Wu, 2011). On the other hand, the constantly growing volume of flights through the hubs may result in congestion at hub airports and create new opportunities for the airports and airlines to provide point-topoint transport services. This model enabled offering services of short-haul flights, with no extra service and low-fare connecting flights to areas that are poorly served or regional airports closed urban areas. This business model also known as a "low cost carrier" model (LCC) provided promising opportunities to regional airports (Sugiyanto et al., 2015). Thus, the sustainable development of the LCC has stimulated the re-evaluation and development of the regional airports.

Although the regional and small airports mainly act as "spokes" and feeders for the main airporthubs, the European Commission has clearly acknowledged their important role in the regional accessibility as well as the potential their to reduce congestion peaks in the central hub-airports, by developing efficient air transport network and improving regional accessibility through better air-rail and air-road access (Urbatzka and Wilken, 2004). The regional airports in Europe may benefit also from Articles 87-89 of the EC Treaties on the financial aid to regional airports and airlines departing from regional airports (EC, 2005). "The regional components of the airport network facilitate access to the core of the network or help to open up peripheral and isolated regions“" (EU, 2005).

\subsection{Air cargo relevance and challenges for the airport development}

O'Conner and William, (2001) state that passenger market in aviation business compared to air cargo market is balanced predictable. Although, airfreight logistics may be named as volatile, cannot function or operate isolated, represents only a single part in value and supply chain and depend on many factors, including country's or regional logistics and informational infrastructure, commercial and policy regulation framework, competitiveness structure, air cargo enables considerably improved the connectivity to distant markets and global supply chains in a fast and reliable manner (Doganis, 2001; Kasarda \& Green, 2005). Growing requirements in terms of time constrains and quality to logistics services triggered development of concepts aiming at efficient organization, improving technical integration and networking of the global economy (Hesse \& Rodrigue, 2004). New drivers and trends in the globalized economy stimulated the air cargo sector to become highly dynamic and flexible, new goods became eligible for air transport, new stakeholders have been entering the market, new concepts and interactions have been developed (Reis \& Macario, 2009). In this context the role of the air cargo transport can be hardly overestimated. In spite of the fact that air transport demands for additional services and logistics requirements, such security, information, financial intensive infrastructure, in the context of just-in-time or just-in-sequence concepts, the air cargo services fulfil already the requirements such as close documentation and secure handling processes. The potential of air cargo exists especially with time-definite or time sensitive products to provide efficient solutions in terms of a time-cost ratio (Ihde, 2001). Furthermore, the 
airports' involvement in the supply chain through air cargo business may strengthen an airport's position in the catchment area (Hübl, 2001). Hübl provided also a number of empirical evidences demonstrating that industrial sites close to airports are generally interesting for production companies and their supply chain activities. Thus, air cargo may positively contribute to the airports' revenue situation (Airline Business, 2005; Boeing, 2015). Several studies evaluating even commercial advantages of airfreight at combined passenger and cargo airports demonstrated that cargo might count as cross-subsidisation for low yields even in the passenger segment (Terhorst, 1992). In the current operational environment, air cargo can be an important source of revenues and be a supplementary factor for profitability (Kasarda \& Green, 2005; Horst, 2006).

Zondag (2006) noted that the relevance of air cargo to airports or airlines heavily depends on air cargo consideration as it might be: core cargo, ancillary or dispensable that might be demonstrated at two levels: 1) route or geographical level, where airports' / airlines profitability in long haul transport services is a main function of the air cargo business since passenger traffic may seldom provide enough revenues to generate a solid profit. Therefore, air cargo plays a key role for keeping routes and market coverage sustainable; 2) company level - for certain airlines, air cargo business seams rather marginal or supplementing activity contributing with as low as up to $4 \%$ of total revenues on other companies airfreight operations may contribute with as much as $50 \%$ of total revenues. The analysis of other researchers showcased that air cargo part in average may represents $15-30 \%$ of airlines' total turnover, whereas the passengers part may be characterised by relatively low margins (up to 7\%) (Reis \& Macário, 2009; Boeing, 2015). The air cargo in the biggest European hub-airports is mostly carried through the intercontinental networks as so called "belly-cargo" in the passenger freighters (cf. Airports Council International 2014). Furthermore, in order to keep the air cargo operations more profitable the airports are utilizing the transfer freight capacities to obtain a sufficient load factor that refers especially to bigger airport-hubs with regular and sustainable transfers made between two long-haul flights that normally have a higher part of transfer air cargo traffic (Boonekamp, 2015). The forwarders establish their own hubs at major airports, where a long-term strategic business is ensured. This leads to an integration of the forwarders' networks for transports to and from the hub airport, which reduces the importance of the hauliers in road feeder networks and of small air cargo stations at feeder airports, because of an exclusion of these destinations from the forwarders' networks (Freye and Steiger, 2004). Boonekamp (2005) noted that on other hand, the participation in the air cargo market of regional airports might be a challenge; since it is rather unrealistic that airlines would offer scheduled air inter-continental (passenger) transport services via regional airports. However, Boonekamp admits that certain regional airports that focused on airfreight, may handle large amounts of cargo through so-called dedicated or full freighters and it might be the niche market for regional airports in this sector. Other researcher also support this idea stating that inter-continental airlines with just one spoke airport might also operate at remote airports under the precondition that this service must be dedicated freighter or pure-freighter traffic without passengers (Schöfer \& Seeck, 2005; Horst, 2006).

\subsection{Air trucking relevance for regional airports in the air cargo market}

As matter of fact, not every flight is a travel option for the air cargo nowadays. LCC do not carry airfreight at all (Boonekamp, 2015). The replacement the air transport mode by road is a growing trend worldwide (Reise, 2009; Boeing, 2015; Beifert, 2015). This model is called as "air trucking" or "road feeder service" (RFS). Efficient road-network infrastructure in Europe has made the development of alternative services to air transport possible via so called air trucking or road feeder services RFS). Due to the fact that majority of the pick up and delivery locations in Europe are rather at short or middle range distances, deployment of RFS often is the fastest, reliable and most cost efficient mode of transportation of the air cargo (Beifert, 2015). Therefore the feeder service fulfilled by a truck provides many advantages, such as higher accessibility e.g. by pick up or delivery services, availability / simplicity in regard to executive units (trucks vs. aircrafts), certain flexibility in regard to an official time-schedule applied for the real air crafts e.g. in form of the given time slots and route. Traditional RFS concept can be defined as a normal truck operating between two airports on so called Air Waybill (AWB) or an air consignment note, which refers to a receipt that is issued by an international airline. It is to note that one truck might have several route numbers or flight numbers if it is carrying goods from more than one airline. Air trucking from the point of view of documentation and security requirements are treated and handled exactly in the same way like real aircrafts, i.e. the "flying trucks" possess herewith exactly the same insurance as if the goods were transported by aircraft and on route number, they are fulfilling all custom and security regulations set by the relevant authorities as if the goods were really flying by air (Grandjot et al. 2007; Heinitz et al. 2013). 
RFS are also used for the air cargo consolidation in the hub/home airport of a given airline. The RFS same as a real aircraft have a fixed time schedule, i.e. in comparison to traditional trucking services, the "flying trucks" dare not wait e.g. till the load capacity of a given truck is used to full extend, but it must leave the point of departure (e.g. Airport A) to a designated destination (e.g. Airport B) at exact time regardless of its current load capacity (Beifert, 2015). The road feeder services mostly belong to the main executive leg in the transport chain and therefore provided and operated by the traditional airlines. Therefore the airlines possess an efficient alternative to deploy RFS for the shipments e.g. from a small or regional airport to a bigger (e.g. international) airport hub. For some airlines RFS present an opportunity to charge of the entire supply chain, i.e. a vertical enlargement of the airlines spectrum (Schüller, 2003). On the other hand, most integrators possess their own supply chain for the front-end logistics, i.e. offering reliable service for timesensitive goods (Turney, 2003). For many European airports the air trucking services count for the biggest part of their total airfreight movements (Vahrenkamp, 2003), e.g. the airfreight share transported by air trucking services at one of the biggest international air-hubs in Europe - Copenhagen Airport in 2014 accounted $40,79 \%$ of the total air cargo volumes excluding integrators; belly cargo: $37,82 \%$, all cargo flights: $13,87 \%$, and mail cargo: $7,59 \%(\mathrm{CPH}, 2015)$.

The considerable increase of RFS role over the past decade has contributed to a strong decline of traditional scheduled airfreight, i.e. carried by air. The number of airport-to-airport pairs more than doubled since 2004 (Boeing, 2015). The main reasons for this trend are costs' and available space optimisation on board aircrafts, particularly those of medium to short haul flights (Heinitz et al., 2013). Heinitz, et al., argued also that RFS have been obtaining more importance as a feeder network for the central airport-hubs, where the long haul network is fed through a short-haul network, here: RFS are mainly applied to acquire freight from "spokes" to fill up long-haul flights. Furthermore, a competitive advantage of air trucking is that implementation and deployment of the air trucking "fleet" does not require intensive financial resources compared to the real or flying cargo. Thus, the increasing demand for transport of the time-critical goods and high-quality of RFS (Derigs et al. 2011) - may give a chance to regional airports to benefit from the air cargo market.

\section{Research gap and research questions}

It may be stated that a wide variety of qualitative research studies and definitions are available nowadays that relate to such subjects as: airport and airline business (e.g. Doganis, 2001; etc.), connectivity in air transport networks (e.g. Veldhuis, 1997; Burhouwt, 2006, Matsumoto et al., 2008; etc.), air cargo and its role in the aviation business (e.g. Sugiyantoa et al., 2015; etc.), supply and demand of the air cargo services (e.g. Taylor \& Hallsworth 2000). However, it might be stated that too less attention has been paid to:

- the special needs and operational requirements of the regional airports;

- the possible role of the air cargo and especially air trucking or road feeder services as a possible business model to enter air cargo market.

Due to the assumptions that regional airports, as it has been stated before, may be positioned as "spokes" or feeders in the air transport network and that the concept of air trucking or road feeder services basically fulfil the "feeding" function it might be assumed that the regional airports may also benefit from air cargo growth and as the first step for the regional airports to enter the air cargo business might be the road feeder services. In the framework of this study the following research questions are investigated:

Research question 1: could air cargo sector be an appropriate supplement or main model of the sustainable business development for regional airports?

Research question 2: if the air cargo segment is an appropriate business model for a regional airport, could the air trucking services might the first step for regional airports to enter the air cargo market, feeding the central air-hub(s) with the air cargo?

\section{Methodology}

Based on the analytical approach for hub-and-spoke airport networks of Sugiyanto, et al. (2015), strategies' evaluation approach of relevance of air cargo business of Reis (2009) and on the qualitative analysis of competitive rivalry in the air cargo industry suggested by Zondag and Willem-Jan (2006), the author of this article is proposing the following evaluation or assessment matrix on the matter of appropriateness and potential of the involvement of regional airports in the air cargo market and the potential of the air trucking serving as a first step. 
Table 1. Matrix assessment of regional airports' potential for air cargo business and RFS

\begin{tabular}{|c|c|c|}
\hline Main criteria element & Assessment indicator & $\begin{array}{l}\text { Weighting } \\
\text { scale }\end{array}$ \\
\hline \multirow{4}{*}{ Air cargo demand side } & $\begin{array}{l}\text { Regional potential of export/ importing industries or businesses, i.e. } \\
\text { Regional business concentration indicator (a) }\end{array}$ & $15 \%$ \\
\hline & $\begin{array}{l}\text { Regional potential of export/ importing industries or businesses, i.e. } \\
\text { Regional density of high-growth enterprises indicator (a) }\end{array}$ & $15 \%$ \\
\hline & $\begin{array}{l}\text { Evaluation of potential customers' awareness for the air cargo services } \\
\text { in the region (b) }\end{array}$ & $5 \%$ \\
\hline & $\begin{array}{l}\text { Estimation of regional air cargo volume potential (b) } \\
\text { (based on airports' classification (EC, 2005) }\end{array}$ & $25 \%$ \\
\hline \multirow{11}{*}{ Air cargo supply side (b) } & Airside/landside access in airports; & $5 \%$ \\
\hline & Apron facilities; & $2 \%$ \\
\hline & Airport's warehouses, special cargo handling facilities; & $5 \%$ \\
\hline & Facilities to service providers; & $2 \%$ \\
\hline & Internal security infrastructure; & $2 \%$ \\
\hline & Airport's operation time (24/7; restricted) & $5 \%$ \\
\hline & Level of airports' air cargo marketing, branding activities; & $2 \%$ \\
\hline & Competition environment of other modes (road, rail) & $5 \%$ \\
\hline & Expansion potential (warehouses, runway, terminals, etc.); & $2 \%$ \\
\hline & Availability of forwarders that may provide RFS & $5 \%$ \\
\hline & Regional road infrastructure (e.g. for RFS); & $5 \%$ \\
\hline
\end{tabular}

(a) data source: secondary data (Eurostat, 2015), (b) data source: primary data (BACN, 2015)

The applied weighting scale of the assessment indicators (incl. the weight distribution between air cargo demand and supply sides) has been based on the overall compilation of the experts' evaluations and the results of the experts' interviews fulfilled in the framework of the BACN project. The BACN experts insisted that for the decision making, if air cargo might be an appropriate sector to participate in, the demand side for air cargo services, especially for regional airports prevails. In the above presented assessment matrix, the author deploys the following weighting scale of the selected criteria:

- air cargo demand side has been given $60 \%$ of the total weighting / importance share for the positive decision-making in favour of air entering / participating in the air cargo business;

- air cargo supply side has been given $40 \%$ of the total weighting / importance share for the positive decision-making in favour of air entering / participating in the air cargo business.

The following assessment presented in this paper has been based on primary and secondary data analysis. The assessment of such criteria as "regional potential of export/ importing industries or businesses, i.e. regional business concentration indicator" and "regional potential of export/ importing industries or businesses, i.e. regional density of high-growth enterprises indicator" has been carried out based on secondary data analysis (Eurostat, 2015), whereas the rest of the indicators have been evaluated based on primary data analysis from BACN project. With regard to the specific air cargo market in the Baltic Sea Region (hereafter: BSR) the current results presented in this paper are based on empirical data, including qualitative expert interviews and surveys produced in the framework of the EU funded research project Baltic.AirCargo.Net (BACN, 2014), financed by the EU Programme "INTERREG IVB, Baltic Sea Region", ERDF Funds. The empirical data was collected from diverse sources of evidence during the project life 2011-2014, i.e. primary empirical data sources in form of qualitative observations of researchers involved into the project activities, external experts' evaluations, project documentation and observations gathered from respective project activities such as workshops, conferences as well as from the field notes from project meetings. Following target groups and relevant stakeholders participated in the surveys and expert interviews a) representatives from Transport Ministries and Airport Management; b) representatives from Transport and Logistics companies from participating regions; c) representatives from the academic side, c) expert from aviation sector, air cargo security and air cargo freight sector. In terms of the presented investigated case studies, 67 qualitative interviews were conducted and evaluated.

Furthermore in order to assess airports' appropriateness for the air cargo business model as well as potential of air trucking services for the air cargo business, an evidence-based approach has been applied in this paper. The case studies of two regional airports from the BSR would be presented. As Yin (2009) pointed out a case study approach draws a special attention on contemporary study issues by addressing strategic question "know-why?". In spite of the fact that the applied qualitative methods here may make it difficult to validate the presented events (Yin, 2009), it may enable to highlight the particularity and complexity of the single case evidences (Stake, 1995). 


\section{Main findings and discussion}

It is to be noted that within the BACN project, in total nine regional airports from eight countries from the Baltic Sea Region have been analysed and evaluated, however only two regional airports have been chosen by the BACN project as so-called pilot cases. The author is presenting these two case studies that have been evaluated on the air cargo business appropriateness with a special focus on promoting of the air trucking concept:

- case study of Tampere Airport (Finland),

- case study of Parchim Airport (Germany).

\subsection{Tampere Airport}

Tampere is the third largest city in Finland, with a population over 340.000 including the metropolitan areas. Tampere is also the largest inland city of all the Nordic countries and a traditional centre of Finnish industry. Today, the city is best known for its high tech and extensive know-how in various fields and has a well educated labour force. Approximately 17.500 enterprises operate within the Tampere central region, of which $80 \%$ employ less than ten persons. The unemployment rate in the Tampere central region is slightly higher than the national average, at approximately $12 \%$. The gross national product per inhabitant is approximately EUR 24.000. Tampere airport is located 174 kilometres from Helsinki Airport, which can be reached in approx. 2 hours by a road. The airport's runway is 2,700 meters long. In 2011, 657,630 passengers passed through the airport, and there were a total of 18,671 landings. The following major production companies are located in the Tampere area: Sandvik (drilling machines), Metso Mining and Construction, AGCO Power (diesel engines), Bronto Skylift (skylifts), Cargotec (straddle carriers etc. container handling equipment). The airport is served by scheduled short haul passenger flights from airBaltic, Blue1 \& SAS, Flybe \& Finnair and Ryanair. The Airport handled in 2011 a total of 542 tons of cargo, a decrease of nearly $20 \%$ compared to 2010 . There are 2 handling companies at Tampere Airport, Airpro OY and Swissport Finland. There are 2 passenger terminals at the Tampere airport, of which only terminal 1 is open on regular basis, and terminal 2 only when Ryan Air have arrivals and departures. BACN experts mentioned that of the biggest weak points for Tampere Airports is the short distance from the main Finnish Airport of Helsinki, which easily can be reached by road in 2 hours. For passengers the airport can only attract short haul feeder flights to larger regional airports, from where there is a large number of connecting international flights to all parts of the world. Therefore, cargo can easily and inexpensively be transported to either the main hub in Helsinki, or even to other international airports in the Nordic region (Copenhagen and Stockholm) as well as in continental Europe such as Amsterdam, Frankfurt, Brussels (BACN, 2014). DHL has previously operated on Tampere Airport, but has moved back to the central hub in Helsinki from where it is easier and more profitable to distribute to whole Finland as well as to neighbouring regions of Russia, i.e. St. Petersburg or Leningrad oblast.

BACN experts also pointed out that low air trucking volumes from other major hubs, like Copenhagen, also arrive to Helsinki and from there goods are distributed by local truck to the rest of the country. It is doubtful, if it is possible to move these flying trucks from Helsinki to Tampere. Most of the local trucking companies are situated in Helsinki, and if they should go to Tampere to pick up the goods this would mean low load capacity and therefore increasing transport costs. The Finnish Red Cross operates their relief flights from Tampere Airport. The Relief cargo is processed though the previous "Fire and Rescue" located at landside near city of Tampere. The Finnish Military also operates air cargo flights from Tampere Airport, however their cargo volumes, destinations, sequences, etc., are the classified information and may not be the object if this study. In order to handle the air cargo for the above flights more efficiently and to improve the attractiveness for both integrators and other cargo operators back to Tampere airport, BACN experts recommended to consider upgrading air cargo facility(ies) at the north east side of the airport. The terminal might be placed on the airside/landside border.

\subsection{Parchim Airport}

Parchim International Airport is situated near Parchim that is a regional town in the State of Mecklenburg-Vorpommern, Germany. The airport has been used for more than 70 years exclusively for the military purposes. In 1992 the airport was taken over by the Parchim County. In 2007 the airport was sold to a private investor, the Chinese company LinkGlobal - International Logistics Group Ltd. that is now the current owner of Parchim airport. The airport has a direct connection to the highway A 24, linking Hamburg and Berlin, as beyond to the German and European long-distance transport network. Rail connections are limited to regional traffic since a direct access to long distance rail lines traffic does not exist. No regular flights are offered at the moment. The geographical / transport and time distance by car from Parchim to the nearest airport hubs are:

- Berlin: $172 \mathrm{~km}$, ca. 2 hours,

- Hamburg: $131 \mathrm{~km}$, ca. 1,5 hour. 
The new owners have planned the internationalization business model for the Parchim airport. The objective was to extend the site to an air cargo hub for transportation between Europe, Africa and Asia. Three flights a week were planned with an option for extension up to 30 flights a day. Furthermore, a sufficient logistics infrastructure was intended. These investments should be made in cooperation with Goodman Group. In 2007 two airfreight connections have been established, one to Zhengzhou (CGO) in the province of Henan and another to Urumqi (URC), the capital of the Xinjiang Uyghur Autonomous Region of the People's Republic of China. The aimed frequency of service on these flight connections could not be achieved at all so far. In 2010 only 8000 tons of air cargo were handled, a volume that has to be considered as completely insufficient to guarantee a cost-effective operation. For this reason more and more capacity utilization problems arise due to the fact that only a low activity rate can be achieved for the personnel and also the technical equipment (aircraft tugs, fire-fighting vehicles, etc.) needed for airport operations as well as for the offered logistic services. The current as well as the to-be expected volumes in air cargo transport are insufficient to generate the necessary revenues for maintaining operations at the airport. Relevant revenues coming from other business areas cannot compensate these deficits. Parchim airport's infrastructure belongs to one of the main tangible resources of Parchim airport: the new tower was built in May 2015, the length of the runway is 3000 meter, the airport has appropriate passengers and cargo terminals, including required security screening technologies. The following attributes have been mentioned by the BACN experts as the airport's distinctive intangible resources, i.e.: low costs operation airport, 24/7 operation, i.e. aircrafts are allowed to land and departure 24 hours daily and 7 days a week; no restriction to night flight operations; all types of aircrafts (incl. AN124 and A380) can be accommodated and handled at the airport, over-size cargo operations are possible; efficient customs services, that makes Parchim Aiport's cargo terminal to dry a port. So called " $24 / 7$ " operation was mentioned as valuable or non-substitutable intangible resource of Parchim Airport. Comparing to other German airports, nowadays a number of official and civil discussion have been started to introduce a night ban for the state owned airports. Since Parchim Aiport is in the private hands, the owners and the airport management claim that in the mid-tem and in the long-term perspective, the 24/7 operation will be still valid for Parchim Airport and might not be questioned. Although considering expanding of the passenger traffic, Parchim Airport is clearly positioning itself as an international gateway to China with a strong focus on the air cargo. According to the current development plan, the airport will be upgraded to ICAO 4F class airport. The experts evaluated the level of value proposition as "good" considering the air-cargo development model and cost-performance ratio. BACN experts noted that although Parchim airport established some strategic functions like marketing and handling staff, the weekly operation, with a B747 cargo aircraft have ceased again after a short period. The cost to operate a B747 cargo to a small regional airport turned out to be too high as all regional aircrafts and trucks to distribute from there had be brought in and the market was too small.

\subsection{Implications for regional airports - air cargo business and air trucking potential}

In accordance to the evaluation matrix presented above (Table 1), the following assessment of two regional airports in the Baltic Sea Region took place, i.e. Tampere Airport and Parchim airport.

Table 2. Matrix Assessment of potential for the air cargo business and RFS

\begin{tabular}{|c|c|c|c|c|c|c|}
\hline \multirow[b]{2}{*}{ Assessment indicator } & \multirow[b]{2}{*}{$\begin{array}{l}\text { Weight } \\
\text { applied }\end{array}$} & \multirow[b]{2}{*}{ Scale applied } & \multicolumn{2}{|c|}{ Tampere Airport } & \multicolumn{2}{|c|}{ Parchim Airport } \\
\hline & & & $\begin{array}{c}\text { Criteria } \\
\text { score }\end{array}$ & $\begin{array}{l}\text { Total } \\
\text { score }\end{array}$ & $\begin{array}{c}\text { Criteria } \\
\text { score }\end{array}$ & $\begin{array}{l}\text { Total } \\
\text { score }\end{array}$ \\
\hline Regional business concentration indicator & $15 \%$ & $4 \max ; 1 \min$ & 2 & 0,30 & 3 & 0,45 \\
\hline Customers' awareness for regional air cargo services region & $5 \%$ & $3 \max ; 1 \min$ & 2 & 0,10 & 1 & 0,05 \\
\hline Estimation of regional air cargo volume potential & $25 \%$ & $4 \max ; 1$ min & 3 & 0,75 & 2 & 0,50 \\
\hline Airside/landside access in airports & $5 \%$ & $4 \max ; 1 \min$ & 3 & 0,15 & 2 & 0,10 \\
\hline Airport's warehouses, special cargo handling facilities & $5 \%$ & $4 \max ; 1 \min$ & 4 & 0,20 & 3 & 0,15 \\
\hline Facilities to service providers & $2 \%$ & $4 \max ; 1 \min$ & 3 & 0,06 & 1 & 0,02 \\
\hline Internal security infrastructure & $2 \%$ & $4 \max ; 1 \min$ & 4 & 0,08 & 3 & 0,06 \\
\hline Airport's operation time (24/7; restricted) & $5 \%$ & $1 \max ; 0$ min & 1 & 0,05 & 1 & 0,05 \\
\hline Airports' air cargo marketing, branding activities; & $2 \%$ & $4 \max ; 1 \min$ & 3 & 0,06 & 1 & 0,02 \\
\hline Competition environment of other modes (road, rail) & $5 \%$ & $1 \max ; 4 \min$ & 3 & 0,15 & 1 & 0,05 \\
\hline Total scoring & $100 \%$ & & & 2,67 & & 2,10 \\
\hline
\end{tabular}


Taking the weighting scoring and the scale applied to the selected indicators in the above presented assessment, the maximum possible scoring will be 3,8 and the minimum possible will be 0,95 ; the following strategic gradation or level of the possible air cargo involvement for regional airports (based on Reis and Macario (2009) and Zondag et al. (2006) combination models of passenger and air cargo businesses) might be presented as follows in Table 3 .

Table 3. Air cargo involvement strategies

\begin{tabular}{|c|c|c|}
\hline $\begin{array}{l}\text { Level of the air cargo business } \\
\text { involvement }\end{array}$ & Strategy description of the level of the air cargo involvement & Scoring \\
\hline No Air Cargo Activity & $\begin{array}{l}\text { The lowest possible level of involvement in air cargo sector for regional airports is } \\
\text { simply not providing airfreight services. In this case scenario air cargo business' } \\
\text { requirements and conditions are not economic competitive or beneficial at all. Air } \\
\text { cargo demand might be very low or marginal e.g. to justify high investment costs in } \\
\text { expansion of air cargo handling facilities }\end{array}$ & $0,95-1,5$ \\
\hline $\begin{array}{l}\text { Outsource Air Cargo Strategy } \\
\text { including RFS }\end{array}$ & $\begin{array}{l}\text { Providing air cargo services with limited or minimum possible commitment. In this } \\
\text { scenario, it might be recommended to develop strategic agreements with third parties, } \\
\text { including freight forwarders, agents, specialised air cargo brokers and also companies } \\
\text { providing Road Feeder Services. On this level the airport's management might focus } \\
\text { more on passenger traffic, costs' optimisation, or trying to improve quality of provided } \\
\text { services by delegating the air cargo business to specialised third party. }\end{array}$ & $1,5-2,5$ \\
\hline $\begin{array}{l}\text { Dedicated Air Cargo Activity, } \\
\text { incl. Air Cargo Charter }\end{array}$ & $\begin{array}{l}\text { Establishing of a pure or dedicated air cargo business operations. This level of } \\
\text { involvement may offer air cargo services airport-to-airport by combi-aircrafts, full } \\
\text { freighters or RFS; as well as a number of other added value services, e.g. tracking and } \\
\text { tracing of goods, customs' services, etc. } \\
\text { This level may imply high level of airport's flexibility (Magalhães et. al., 2013), i.e. } \\
\text { finding most optimal ways without big financial investments or airport's restructuring } \\
\text { measures. Due to relatively high demand for air cargo services, dedicated air freighter } \\
\text { might be deployed offering also intermodal transport services, i.e. airport-to-door, } \\
\text { door-to-airport and door-to-door services. }\end{array}$ & $2,5-3,5$ \\
\hline $\begin{array}{l}\text { Air Cargo Expansion } \\
\text { Strategy }\end{array}$ & $\begin{array}{l}\text { This air cargo involvement level may imply air cargo market expansion strategy, e.g. } \\
\text { by establishing of a subsidiary representation of a given airport in other airport(s). } \\
\text { Subsidiary unit may offer gull range of air cargo services that also may be } \\
\text { independently defined (Reis and Macario, 2009). }\end{array}$ & above 3,5 \\
\hline
\end{tabular}

Based on the above mentioned scheme and fulfilled assessment of the regional airports (here: Tampere Airport and Parchim Airport), the both research questions of this paper (Q1: if air cargo sector could be an appropriate supplement or main model of the sustainable business development for regional airports; and Q2: if the air trucking services might the first step for regional airports to enter the air cargo market, feeding the central air-hub(s) with the air cargo) might be answered positively.

The airport management of Parchim Airport since approximately 2007 has been trying implement air cargo involvement strategy "Dedicated Air Cargo Activity". The expert evaluation, however, fulfilled on the basis of the presented assessment matrix would rather suggest concentrating first on "Outsource Air Cargo Strategy including RFS". The first successful start indeed, might be the deployment and efficient utilization of the air trucking services. On the other hand, during the project BACN implementation period (2011-2014), Tampere Airport had been trying to establish air trucking service connection to Helsinki Airport, so far without success. However, due to relatively high demand for the air cargo services and also good supply side, it might be recommended to Tampere Airport to start to think of implementation of "Dedicated Air Cargo Activity", acting as a "spoke" to establish a regular / scheduled pure freighter connection to an international air-hub, e.g. to Copenhagen or Stockholm Airport.

\subsection{Discussion}

Generally it may be noted that during last decade, the regional airports in Europe and the Baltic Sea Region have improved point-to-point carriers operations due to sustainable growth of low cost carrier business model. The supply side of the air transport services within Europe has risen considerably; the competition among both airports and airlines has increased. Such "positive" consequences for passengers as: lower fares, increased frequencies and more destinations result also in lower revenues for the airports and airlines. Trans European air cargo of the Baltic Sea Region is mostly handled by the airports, which have intercontinental passenger flights: significant part of the Baltic Sea Region air cargo is utilizing belly cargo concept and intercontinental passenger flights operated by so called wide-body aircrafts. These airports are typically capital airports like Copenhagen Airport, Stockholm Airport and Helsinki Airport. Also the major part of the Baltic Sea Region freighter flights is operating to the same capital airports, which have the belly cargo flows. On the other hand, it can be generally noticed that in aviation business within the Europe (here: intra European air 
transport) the passengers are flying, but the air cargo is mainly delivered by trucks, i.e. Road Feeder Services. However, due to the highly competitive air cargo market environment, it very difficult for regional airports to be competitive or profitable in this business segment. The traditional business model: i.e. airport-to-airport transport services, whereas an airline functions as a carrier and all other services are provided by a forwarder on behalf of the shipper, could hardly be suitable for regional airports today. Facing also the upcoming challenges in form of the cuts of the public aid, the regional airports must adopt their development strategies to be able to operate on more cost efficient and profitable basis.

As it has been indicated by a number of BACN experts, the inter-dependency between accessibility of the Baltic Sea Region and the hub-and-spoke transport system may be further discussed and investigated in other research studies. The most of the remote areas of the BSR could not reach the same accessibility (e.g. number of transport routes, destinations) as the central regions. In the current aviation transport market, the air-hubs like Copenhagen, Stockholm or Hamburg) offer intercontinental flight connections and the feeder traffic (e.g. flying truck, Road Feeder Service) is the spoke between the hub and the hinterland. Therefore, it can be further discussed, if that the Road Feeder Services along with the strong impact on the air cargo market might support the intercontinental passenger flights and the major air-hubs in the Baltic Sea Region and in whole Europe, since major aviation hubs of the BSR influence the accessibility of the BSR significantly, whereas the economic viability of the intercontinental passenger flights depends on the efficiency and profitability of the air cargo business.

The distribution of the importance or "weight" between the assessment criteria in the presented assessment model may represent a subject of future disputes and discussions. The experts of the BACN project pointed out that although this weighting scale might be very subjective, however the weighting scale needs to be integrated in this or another form in the evaluation process, since the assessment criteria are not equal. It has been further noted by BACN experts that this weighting scale is not a "universal" for every regional airport, but on the contrary the evaluation approach and the correspondingly applied weighting scale must be very individual, respecting the regional peculiarities, economic perspectives and regional stakeholders' interests.

Furthermore, air-trucking services might be the driving force for the regional entrepreneurship development in the operational environment of an airport. The technical implementation of RFS concept does not require considerable financial resources compared e.g. to the real airlines by deploying air-carriers and corresponding airport infrastructure. The pure air cargo sector implies big infrastructural investments, e.g. for the buying, leasing, maintaining of the aircrafts. On the other hand, according to the BACN project's results, only few air cargo companies in the BSR have real aircrafts' fleet, i.e. the whole airfreight "fleet" of majority of air cargo forwarders consists of trucks that deliver air cargo via air trucking services. Compared to big companies SMEs by providing such services may gain an essential competitive advantage in the air cargo supply chain, due to their traditional flexibility and innovative approaches.

\section{Conclusions}

Aviation industry, both airports and airlines, are facing strong competition and the Baltic Sea Region and the possibilities that are being offered by air cargo market and the concept of Road Feeder Service may strengthen the economic viability of the airports and the regions. The air cargo business may offer to the regional airports a supplementary opportunity to the passenger traffic, thus making an airport more profitable and attractive for regional business structures. Although the regional and small airports mainly act as "spokes" and feeders for the main airport-hubs, the efficient deployment of appropriate strategies, integration in the air cargo supply chain) may bring many advantages not only to the main stakeholders like airports and airlines themselves, but also to the regional community in terms of economic and social benefits, as well as improved accessibility. Belly cargo concept would almost be impossible to implement by regional airports since it is based on the intercontinental passenger flights. The freighter concept would be basically possible; however its implementation would require sustainable air cargo volume (approximately ore than 200 tons per week in and out). Thus, the Flying trucks concept might be at this time the only one realistic concept for remote and / or regional airports when they are trying to access to the air cargo market.

The above-presented results, as well as the results of the BACN Project showcase that the regional airports shall recognize and accept the usability of the Road Feeder Service or air-trucking concept much stronger than they do it today. Some other results of the BACN project pointed also out that relevant EU transport strategies clearly underestimate potential and the growing role of air trucking. Thus, it is of a vital importance to raise public and political awareness of the RFS concept and its role in the international logistics network, for it shall be more efficiently adapted to the EU and BSR transport policies as well as to regional development strategies. 


\section{References}

1. Bailey, E., Graham, D.R., Kaplan, D.P. (1985) Deregulating the Airlines. Cambridge, MA: The MIT Press.

2. Barrett, S.D. (2000) Airport competition in the deregulated European aviation market. Journal of Air Transport Management, 6 (1), pp. 13-27.

3. Bauer, P. (1987) Airline Hubs: A Study of Determining Factors \& Effects. Federal Reserve Bank of Cleveland, Economic Review, vol. 23, no. 4, pp. 13-19.

4. Beifert, A. (2015) Business Development Models for Regional Airports - Case Studies from the Baltic Sea Region. Journal of Security and Sustainability, Issues, 5, pp. 199-212.

5. Boonekamp, T. (2014) Network quality and catchment area analysis in the air cargo industry. SEO Economic Research. Amsterdam.

6. Bootsma, P.D. (1997) Airline flight schedule development; analysis and design tools for European hinterland hubs, Utrecht, University of Twente.

7. Bottler, S. (2006) Truck statt Turbine. Verkehrs-Rundschau 36, pp. 46-49.

8. Burghouwt, G., Redondi, R. (2013) Connectivity in Air Transport Networks: An Assessment of Models and Applications, Journal of Transport Economics and Policy (JTEP), Volume 47, Number 1, January 2013, pp. 35-53(19).

9. Burghouwt, G., Veldhuis, J. (2006) The competitive position of hub airports in the Transatlantic market. Journal of Air Transportation, 11(1): 1071-30.

10. Crabtree, T., Hoang, T., Edgar, J. (2015) World Air Cargo Forecast 2014-2015. Boeing Commercial Airplanes, Seatle.

11. Dennis, N. (1994) Airline hub operations in Europe. Journal of Transport Geography, 2:4, pp. 219-233.

12. Derigs, U., Kurowsky, R., Vogel, U. (2013) A Solving a real-world vehicle routing problem with multiple use of tractors and trailers and EU-regulations for drivers arising in air cargo road feeder services. European Journal of Operational Research, 213 (2011), pp. 309-319.

13. Doganis, R. (2001) The airline business in the twenty first century. Routledge, New York.

14. Freye, H., Steiger, D. (2004) Konzentration der Luftfracht - wo hat sie stattgefunden? Fraunhofer ILM, Aviainform, Frankfurt.

15. Fewings, R. (1999) Provision of European airport infrastructure. Avmark Aviation Economist, July 1999, pp. 18-20.

16. Gardiner, J., Humphreys, I., \& Ison, S. (2005) Factors influencing cargo airlines' choice of airport: An international survey, Journal of Air Transport Management, 11(6), pp. 393-399.

17. Grandjot, H-H., Roessler, I. (2007) Air Cargo Guideline, Munich, pp. 86-88, 271.

18. Ihde, G.B. (2001) Transport, Verkehr, Logistik. Munich: Vahlen.

19. Heinitz, F., Hirschberger, M., \& Werstat, C. (2013) The role of road transport in scheduled air cargo networks. 2nd Conference of Transportation Research Group of India (2nd CTRG), Procedia - Social and Behavioral Sciences, 104 (2013), pp. 1198 - 1207.

20. Hesse, M., Rodrigue, J.P. (2004) The transport geography of logistics and freight distribution. Journal of Transport Geography,12, pp. 171-184.

21. Horst, M. (2006) The role of German regional airports in logistics networks. PhD Dissertation, Molde.

22. Hübl, L., Hohls-Hübl, U., Wegener, B., Schaffner, J. (2001) Hannover Airport - Ein Impulsgeber für die Region. Beiträge zur regionalen Entwicklung, Heft Nr. 84. Hannover: Kommunalverband Großraum, Hannover.

23. Kasarda, J.D., Green, J.D. (2005) Air cargo as an economic development engine: A note on opportunities and constraints. Journal of Air Transport Management, 11, pp. 459-462.

24. Kupfer, F., Goos, P., Kessels, R., Van de Voorde, E., Verhetsel, A. (2011) The Airport Choices in the Air Cargo Sector - A Discrete Choice Analysis of Freighter Operations, European Transport Conference 2011, Glasgow.

25. Magalhães, L., REIS, V., Macário, R. (2013) Airport Flexibility: A First Glimpse On The External Factors. 13th World Conference on Transport Research, Rio de Janeiro.

26. Matsumoto, H. Veldhuis, J., de Wit, J., Burghouwt, G. (2008) Network performance, hub connectivity potential, and competitive position of primary airports in Asia/Pacific region. Air Transport Research Society Conference, June 2008, Athens.

27. Morrison, S., Winston, C. (1986) The Economic Effect of Airline Deregulation. Washington, D.C.: Brookings Institution.

28. De Neufville, R. (2008) Low-Cost Airports for Low-Cost Airlines: Flexible Design to Manage the Risks. Transportation Planning and Technology. Vol. 31, No. 1, pp. 35-68. 
29. O’Connor, William (2001) An introduction to airline economics, 6th edition, Praeger Publishers, Westport (United States), p. 162.

30. Reynolds-Feighan, A., McLay, P. (2006) Accessibility and attractiveness of European airports: a simple small community perspective. Journal of Air Transport Management, (12): pp.313-323.

31. Reis, V., Macário, R. (2009) Spectrum of competitiveness of passenger airlines on air cargo market. Air Transport Research Society Conference, 27-30 June, Abu Dhabi.

32. Rietveld, P., Brons, M. (2001) Quality of hub-and-spoke networks; the effects of timetable coordination on waiting time and rescheduling time, Journal of Air Transport Management, 7, pp. 241249.

33. Shuchi, S; Drogemuller, R; Kleinschmidt, T. (2012) Flexible Airport Terminal Design: Towards a Framework. Proceedings of the IIE Asian Conference 2012, Furama Riverfront Hotel, Singapore, pp. 348-356.

34. Schöfer, J., Seeck, S. (2005) Vertikale strategische Partnerschaften als Erfolgsfaktor in der Luftfracht. Internationales Verkehrswesen. May (57), pp. 196-200.

35. Schüller, M. (2003) Wettbewerbsvorteile durch Supply Chain Management. Neue Märkte für Cargo Airlines. Internationales Verkehrswesen. October (55), pp. 483-484.

36. Stake, R. E. (1995) The Art of Case Study Research, Sage Publications, Thousand Oaks: California.

37. Starkie, D. (2002) Airport regulation and competition, Journal of Air Transport Management, 8, pp. 63-72.

38. Sugiyantoa, G., Santosaa, P.B., Wibowoa, A, Santib, M.Y. (2015) Analysis of hub-and-spoke airport networks in Java Island, based on cargo volume and freight ratio, The 5th International Conference of Euro Asia Civil Engineering Forum (EACEF-5), Procedia Engineering 125 (2015), pp. 556 - 563.

39. Taylor, M., Hallsworth, A. (2000) Power relations and market transformation in the transport sector: the example of the courier service industry. Journal of Transport Geography, (8), pp. 237-47.

40. Terhorst, R. (1992) Das Modell eines Frachtflughafens und sein Beitrag zur logistischen Optimierung der Luftfrachttransportkette. PhD dissertation.

41. Turney, R. (2003) Virtual Airports. Air Cargo World, December (93), pp.15-17.

42. Urbatzka, E., Wilken, D. (2004) Future airport capacity utilisation in Germany: Peaked congestion and/or idle capacity. Journal of Air Transportation, Vol. 9, No. 2, pp.111-132.

43. Vahrenkamp, R. (2003) Der Gütertransport im internationalen Luftverkehr. Internationales Verkehrswesen. March (55), pp. 71-75.

44. Veldhuis, J. (1997) The competitive position of airline networks. Journal of Air Transport Management, 3(4): 181-188.

45. Veldhuis, J., Kroes, E. (2002) Dynamics in relative network performance of the main European hub airports. European Transport Conference, Cambridge.

46. White, L., J. (1979) "Economies of Scale and the Question of "National Monopoly" in the Airline Industry," Journal of Air Law and Commerce, vol. 44, no. 3, pp. 545-573.

47. Wei, S., Yanji, M. (2006) Hub-and-Spoke System in Air Transportation and Its Implications to Regional Economic Development-A Case Study of United States, Chinese Geographical Science, 2006 16(3), pp. 211-216.

48. Wu, C., Han, J., Hayashi, Y. (2011) Airport Attractiveness Analysis through a Gravity Model: A Case Study of Chubu International Airport in Japan, Proceedings of the Eastern Asia Society for Transportation Studies, Vol.8.

49. Yin, R. K. (2009) Case Study Research: Design and Methods, Sage Publications: London 2009, p. 2.

50. Zondag, W.J. (2006) Competing for air cargo - a qualitative analysis of competitive rivalry in the air cargo industry, Master Thesis, Free University of Amsterdam, Amsterdam.

Web sources:

51. Air Transport Research Society (2015) "2015 ATRS Benchmarking Report” (ATRS, 2015): http://www.atrsworld.org/docs/Key\%20Findings $\% 20$ of $\% 20 \% 202015 \% 20$ ATRS $\% 20$ Benchmarking. pdf (access: January 2016)

52. Boeing (2015) "World Air Cargo Forecast 2014-2015": http://www.boeing.com/resources/boeingdotcom/commercial/about-our-market/cargo-market-detailwacf/download-report/assets/pdfs/wacf.pdf (access: January 2016)

53. Copenhagen Airport (2016) Air cargo statistics of Copenhagen Airport (CPH, 2016): https://www.cph.dk/en/about-cph/b2b/airline-sales/cargol/trafikstatistik/ (access: January 2016)

54. Baltic.AirCargo.Net (2014) INTERREG IVB Programme, Baltic Sea Region 2007-2013, ERDF Funds (BACN, 2014): http://www.balticaircargo.net (access: December 2015) 
55. Parchim Airport: http://www.parchim-airport.com/en/html/index.asp (access: January 2016)

56. Tampere Airport: https://www.finavia.fi/en/tampere-pirkkala/ (access: January 2016)

57. Structural business statistics at regional level (Eurostat, 2016): http://ec.europa.eu/eurostat/statisticsexplained/index.php/Structural_business_statistics_at regional level (Access: January 2016)

Relevant policy regulations, reports and guidelines:

58. EU Commission (2014) Competition Policy Brief on the New State aid rules for a competitive aviation industry, Competition Directorate-General of the European Commission, Brussels

59. EU Commission (2005) Community Guidelines on Financing of Airports and Start-up aid to Airlines departing from Regional Airports. Brussels: European Commission (2005/C 312/ 01)

60. IATA (2000). Global Airport Connectivity Monitor. IATA - Hague Consulting Group

61. US Congress (1978) Airline Deregulation Act of 1918, PUBLIC LAW 95-504-OCT. 24, 1978 